Original Research Paper

\title{
Potential Role of Migratory Quail in Spreading of Some Zoonotic Pathogens in Egypt
}

\author{
${ }^{1}$ Ahmed I. Youssef and ${ }^{2}$ Dalia H. Mansour \\ ${ }^{1}$ Department of Animal Hygiene and Zoonosis (Division of Zoonosis), \\ ${ }^{2}$ Department of Poultry and Rabbit Medicine, \\ Faculty of Veterinary Medicine, Suez Canal University, 41522, Ismailia, Egypt
}

Article history

Received: 27-05-2014

Revised: $10-07-2014$

Accepted: 28-11-2014

Corresponding Author:

Dalia H. Mansour

Department of Poultry and

Rabbit Medicine, Faculty of

Veterinary

Medicine, Suez Canal

University, 41522, Ismailia,

Egypt

Email: Dalia97.mh@gmail.com

\begin{abstract}
This study aimed to illustrate the potential role of wild migratory quails in the epidemiology of some zoonotic pathogens in Egypt. Ninety four apparently healthy migratory quails were collected from public markets after being trapped during hunting season from the North Sinai. Oral, cloaca and organs (liver, lung and heart) swabs were collected for bacteriological and viral examination. Bacteriological examination revealed high percentage of lactose fermenter bacteria (48.9\%) including E. coli spp. (37.2\%) and Salmonella spp. (24.4\%). Three out of $12(25 \%)$ of Salmonella spp. Isolates were S. enterica subspecies typhimurium. Other bacteria isolation rate was differed such as Staphylococcusaureus spp. (19.1\%), Proteus spp. (7.4\%), Listeria spp. (4.2\%) and Klepsila spp. (3.1\%). E. coli spp. and Salmonella spp. isolates were further examined by API20and PCR techniques. Antibiogram testing against 32 E. coli spp. and 12 Salmonella spp. isolates, revealed multi-drug resistance pattern and high sensitivity to enrofloxacin, nitrofuranation and ofloxacine. Parasitological examination revealed that $35(37.2 \%)$ quails were infected with chewing lice (Phithiraptera spp.). Intestinal infection with Heterakis spp. and/or Ascarida spp. Was detected in $27(28.7 \%)$ quails. All quails were negative for avian influenza virus by direct detection by Rt-PCR for oral and cloaca swabs followed by inoculation in embryonated chicken eggs. In conclusion, the migratory quails might play a potential role in dispersion of zoonosis in Egypt.
\end{abstract}

Keywords: Quails, Migratory Birds, Bacteria, Parasites, Viruses, Zoonosis

\section{Introduction}

Migratory quail, known as common quail (Coturnix coturnix), is one of the most migratory birds migrates from Europe to Egypt during autumn. During the hunting season, many thousands of these birds are caught in hunter nets on arrival to Mediterranean shore of the North Sinai, Egypt. As other migratory birds, migratory quail act as possible (biological and/or mechanical) vectors playing role in the ecology and circulation of some zoonotic pathogen threatening human health and domestic animals (Abulreesh et al., 2007; Benskin et al., 2009). These zoonotic pathogens cause losses of efficient production and quality of food of animal origin (Acha and Szyfres, 1987; Stohr and Melsin, 1997; Kahn, 2006). Migratory quails pose a risk of transmission of many zoonotic diseases to hunters or consumers who handle or eat these birds by either direct or indirect contact (Smith, 1999). Moreover, wild birds encourage new health problems in wildlife population to emerge, as well as novel reservoir of zoonotic disease could be transmitted and emerge from one continent to another by migratory birds (Cole et al., 2005).

Escherichia coli and Salmonella are considered as the principal causes of morbidity and mortality, associated with heavy economic losses to the poultry industry. Other zoonotic pathogens such as Staphylococcus spp. and Proteus spp. are considered the most important bacterial pathogen isolated from migratory quails (Mohamed et al., 2001; Effat and Moursi, 2005). Moreover, the development of antimicrobial resistant strains of zoonotic bacteria constitutes a public health risk, increasing risk of treatment failures (Middleton and Ambrose, 2005).

Avian influenza AI viruses constitute global health concern. Susceptibility to AI Viruses (AIV) varies deeply among wild bird and poultry species, as well as their possible role as vectors, intermediate hosts or reservoirs. Quails could play a key role in AIV 
epidemiology (Bertran et al., 2011). It is proposed that quails may generate new re-assortant influenza viruses (Thontiravong et al., 2012).

This study aimed to evaluate the occurrence of some zoonotic pathogens which could be transmitted by wild quails in Egypt as well as studying the antibiotic resistance of some isolated bacterial strains.

\section{Material and Methods}

\section{Bird Collection}

Ninety four apparently healthy live migratory quails were collected from the public markets in two different geographic locations namely Ber-Elabd and Romana (Fig. 1) across the shore of Mediterranean sea in the North of Sinai, Egypt during hunting season (5th and 20th September and 5th October 2012). All birds were live trapped through nets before being sold out in the markets. Quails were delivered quickly to the laboratory.

\section{Sample Collection}

After being delivered to the laboratory, quails were kept under observation for $24 \mathrm{~h}$ for clinical examination. Oral and cloaca swabs were collected in two sets tubes, the first contained $10 \mathrm{~mL}$ buffered peptone water for bacterial isolation and the second contained $10 \mathrm{~mL}$ of Phosphate-Buffered Saline (PBS) solution with antibiotic for viral isolation. Swabs were collected from organs (heart, liver and lung) under aseptic conditions. Intestines were directly opened during postmortem examination and were examined for presence of adult helminthes.

\section{Bacteriological Examination}

\section{Isolation and Identification of Bacteria}

Swabs pre-enrichment was performed in buffered peptone water (LabM) at a temperature of $37^{\circ} \mathrm{C}$ for $18-24$ $\mathrm{h}$ followed by plating onto MacConkeyagar (OXOID, Hampshire, UK) and incubated at $37^{\circ} \mathrm{C}$ for $24 \mathrm{~h}$. The lactose fermenting colonies suspected to E. coli were reinoculated to Eosin Methylene Blue (EMB) agar. Colonies producing metallic sheen were suspected to E. coli strains.

For Salmonella spp. isolation, pre-enrichment was followed by selective enrichment in RappaportVassiliadis (OXOID, Hampshire, UK) at $42^{\circ} \mathrm{C}$ for $24 \mathrm{~h}$ followed by plating on Xylose, Lysine and Desoxycholate (XLD) (LabM) and incubation at $42^{\circ} \mathrm{C}$ for $24 \mathrm{~h}$. Suspected E. coli, Salmonella, Proteus spp. and Keilbseilla spp. were biochemically identified according to Edwards and Ewing (1972)? Furthermore, suspected E. coli, Salmonella isolates were confirmed using the API 20 test (bioMe'rieux, France). Multiplex PCR was used for identifying S. Enteric serovars typhimurium and enteritidis.

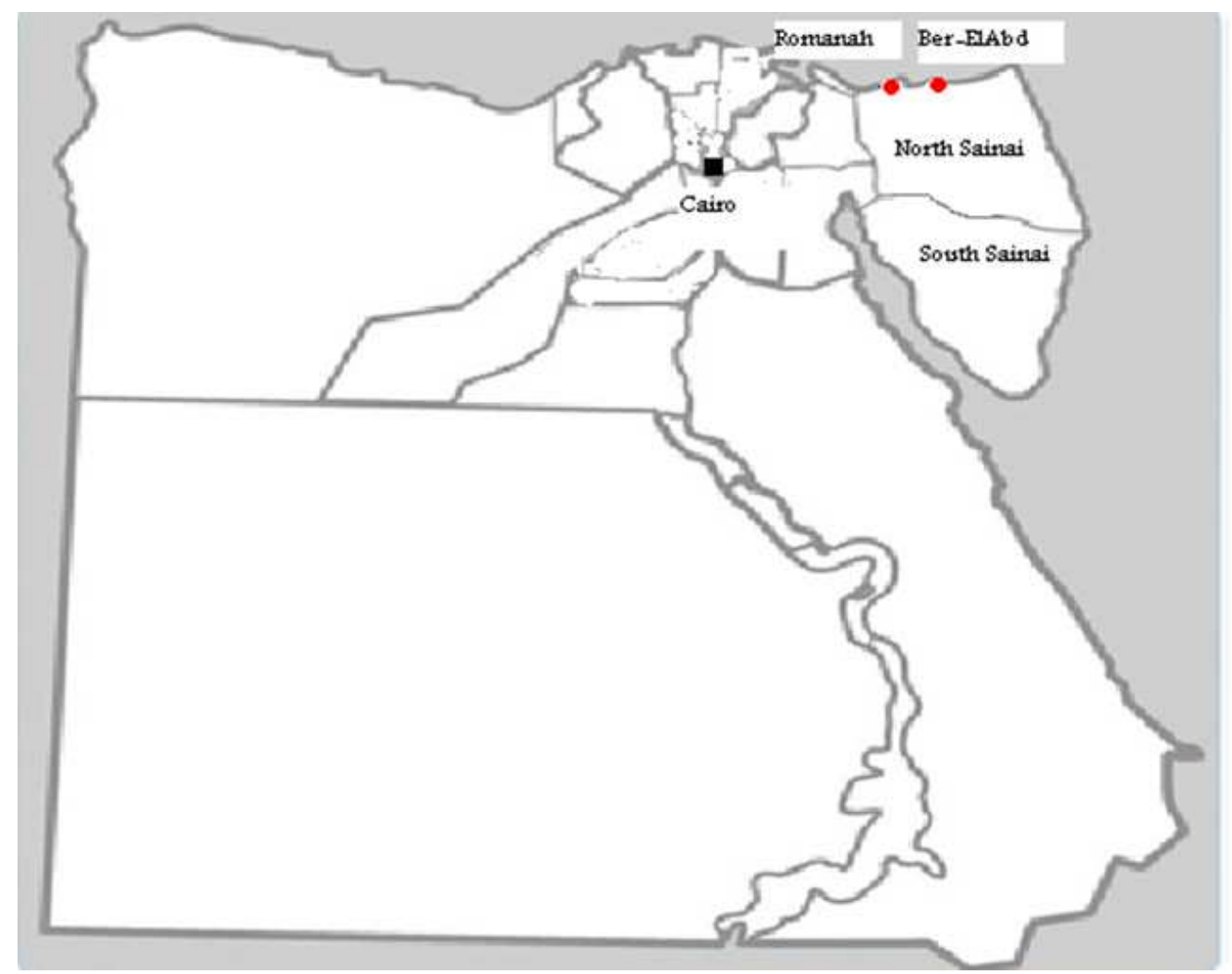

Fig. 1. Map of Egypt showing the areas of sample collection referred as two red dots 


\section{Isolation and Identification of S. Aureus}

Pre-enrichment swabs were plated onto selective Mannitol salt agar (LabM) and cultured at $37^{\circ} \mathrm{C}$ for $24-$ $48 \mathrm{~h}$. Colonies were identified according to Kloos and Bannerman (1999). S. aureus strain, Designation; NCTC7447/ATCC $® 6538$ P was used as control positive.

L. monocytogenes was isolated by pre-enrichment broth incubated at $30^{\circ} \mathrm{C}$ for $48 \mathrm{~h}$ for followed by plating on Listeria Isolation Media, Oxford (ISO) with selective additives (LabM). Grey colonies with black halo were identified as $L$. monocytogens after incubation at $37^{\circ} \mathrm{C}$ for $48 \mathrm{~h}$.

\section{DNA Extraction and PCR Amplifications}

Bacterial DNA was extracted from cultured broth by centrifugation at $4^{\circ} \mathrm{C}$ at $3,000 \times \mathrm{g}$ for $10 \mathrm{~min}$. The pellet was washed twice with PBS and the cells were resuspended in $800 \mu \mathrm{L}$ of sterile distilled water and boiled for $10 \mathrm{~min}$. The resulting solution was centrifuged at $3,000 \times \mathrm{g}$ for $10 \mathrm{~min}$ and the supernatant was used as the DNA template. Amplification reactions were carried out with $5 \mu \mathrm{L}$ of boiled bacterial suspensions, $5 \mu \mathrm{L}$ of $5 \mathrm{X}$ Taq Master Mix/high yield (Jena Bioscience, GMBH, Germany) and two pairs of each primer 50 pmol. Distilled water was added to bring the final volume to 25 $\mu$ L. E. coli spp. isolates; general primers were used in PCR amplification of $670 \mathrm{pb}$ segment of Glutamate Decarboxylase (GAD) gadA/B gene according to McDaniels et al. (1996). Positive microbiological Salmonella were confirmed and serotyped as typhymurium and enteritidis by using multiplex PCR using three sets of primers were used for PCR as described previously by Alvarez et al. (2004). S. aureus isolates were confirmed by amplification of $16 \mathrm{SrRNA}$ gene according to Monday and Bohatch (1999) that generated a 228-bp amplicon during the amplification process. PCR conditions were started by initial denaturation step of $2 \mathrm{~min}$ at $95^{\circ} \mathrm{C}$, followed by 30 cycles of $95^{\circ} \mathrm{C}$ for $30 \mathrm{~min}, 57-60^{\circ} \mathrm{C}$ for $30 \mathrm{~s}$ and $72^{\circ} \mathrm{C}$ for $30 \mathrm{sec}$. The reaction was terminated with $10 \mathrm{~min}$ incubation at $72^{\circ} \mathrm{C}$. The PCR reaction products were subjected to electrophoresis in a $1.5 \%$ agarose gel, stained with ethidium bromide and visualized and photographed under UV light. Products of the appropriate sizes were identified by comparisons with a 100 bp DNA ladder (Gibco). In each PCR run, a non-template control was included to detect possible external DNA contamination and control positive were used for confirmation.

\section{Antimicrobial Susceptibility Testing}

Susceptibility of the isolates to 13 types of antibiotics was performed using the standard Kirby-Bauer method. The isolates were inoculated in nutrient broth at $30^{\circ} \mathrm{C}$. Commercially available discs (Oxoid, UK) containing Amoxicillin (AMC) (20+10), Cefotaxime (CTX)(30) and
Ciprofloxacin (CIP)(5), claveulinic, clindamycin (DA)(2), colistin (10), Erythromycin (E)(15), gentamycin $(\mathrm{CN})(10), \quad$ Oxytetracycline $\quad(\mathrm{T})(30)$, Sulbactin-Ampicillin (SAM) $(10+10)$, Trimethoprim Sulphamethoxazole (SXT) $(1.25+23.75)$, Nitrofuranation (F300), Ofloxacin (OFX)(5), Enrofloxacine (ENR)(10) were placed on the surface of the Muller Hinton agar plates and incubated at $30^{\circ} \mathrm{C}$ for $24 \mathrm{~h}$. The diameters of inhibition zones formed surrounding each isolate were measured inclusive diameter of the discs. Results were expressed assusceptible $(21 \mathrm{~mm})$; intermediate $(16$ to 20 $\mathrm{mm})$ or resistant $(\leq 15 \mathrm{~mm})$ followed a standard range (Liasi et al., 2009). All isolates were tested duplicate for each type of anti-bioticin accordance with the criteria of the Clinical Laboratory Standards Institute, formerly guidelines (NCCLS, 2009). Antibiotic discs used and its concentrations were shown in Table 2.

\section{Parasitological Examination}

The birds were examined for external parasite and then necropsied for examining of intestine for helminthes parasites. Adult helminthes detected by naked eye were individually recovered, fixed and stored for later identification.

\section{Influenza Virus Isolation and Identification}

Oral and cloaca swabs were detected by direct by RT-PCR and by inoculation in 10-day-oldembryonated specific- pathogen-free SPF eggs through allantoic sac route. The inoculated eggs were held at $37^{\circ} \mathrm{C}$ and candled daily for 5 days. The allantoic fluid was collected and tested by RT-PCR. Swabs were tested for the presence of influenza A viruses by detection of the Matrix (M) gene, using a viral RNA extraction kit (QIAamp, QIAGEN, Germany) and a one-step real-time RT-PCR kit (Quantitect, QIAGEN, Germany). The test was conducted in a Stratagene MX3005P real-time PCR machine (La Jolla, CA) using protocol that was previously described by Aly et al. (2008).

\section{Results}

\section{Clinical and Post-Mortem Examination}

All quails were apparently healthy. Post-mortem examination did not indicate any abnormalities except adult helminthes in the intestine and the ceca.

\section{Occurrence of most Pathogenic Bacteria in Oral and Cloaca Swabs}

As illustrated in Table 1, results of bacteriological examination revealedhigh percentageforlactose fermenter isolates (48.9\%); including E. coli spp. (37.2\%), Salmonella spp. (24.5\%). S. typhimurium was identified in 3 out of $12(25 \%)$ of Salmonella spp. isolates while none of Salmonella spp. isolates was identified as $S$. Enteritidis by PCR technique. 


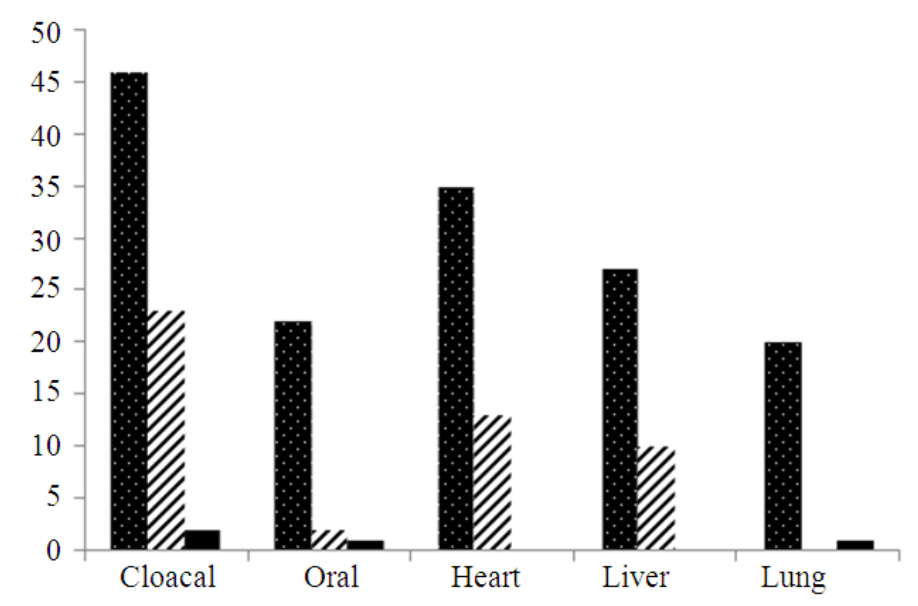

Fig. 2. Rate of isolation of E.coli spp. Salmonella spp. and S. aureus from different body sites

Table 1. Incidence of most zoonotic pathogens isolated from examined quails

\begin{tabular}{|c|c|c|c|c|c|c|}
\hline Collection times & $\begin{array}{l}\text { E. coli } \\
+ \text { ve } \\
\%\end{array}$ & $\begin{array}{l}\text { Salmonella spp. } \\
+ \text { ve } \\
\%\end{array}$ & $\begin{array}{l}\text { S. aureus } \\
\text { +ve } \\
\%\end{array}$ & $\begin{array}{l}\text { Proteus spp. } \\
+ \text { ve } \\
\%\end{array}$ & $\begin{array}{l}\text { Listeria spp. } \\
+ \text { ve } \\
\%\end{array}$ & $\begin{array}{l}\text { Klepsiala spp. } \\
+ \text { ve } \\
\%\end{array}$ \\
\hline \multirow[t]{3}{*}{$1 \mathrm{st}(\mathrm{n}=34)$} & 11 & 10 & 7 & 2 & 1 & 1 \\
\hline & $11.7 \%$ & $10.6 \%$ & $7.4 \%$ & $2.1 \%$ & $1.06 \%$ & $1.06 \%$ \\
\hline & 19 & 8 & 10 & 4 & 2 & 2 \\
\hline $2^{\text {nd }}(n=40)$ & $20.2 \%$ & $8.5 \%$ & $10.6 \%$ & $4.2 \%$ & $2.1 \%$ & $2.1 \%$ \\
\hline $3 \mathrm{rd}$ & 5 & 5 & 1 & 1 & 1 & 0 \\
\hline $\mathrm{n}=20$ & $5.3 \%$ & $5.3 \%$ & $1.06 \%$ & $1.06 \%$ & $1.06 \%$ & $0 \%$ \\
\hline Total & 35 & 23 & 1819. & 7 & 4 & 3 \\
\hline$n=94 \%$ & $37.2 \%$ & $24.4 \%$ & $1 \%$ & $7.4 \%$ & $4.2 \%$ & $3.1 \%$ \\
\hline
\end{tabular}

Table 2. Comparative efficacy of antibiotic sensitivity of 16 antimicrobials against isolates collected from heart

\begin{tabular}{|c|c|c|c|c|c|c|}
\hline \multirow[b]{2}{*}{ Antimicrobial agent code } & \multicolumn{3}{|c|}{ E. coli spp. } & \multicolumn{3}{|c|}{ Salmonella spp. } \\
\hline & $\mathrm{S}$ & M & $\mathrm{R}$ & $\mathrm{S}$ & $\mathrm{M}$ & $\mathrm{R}$ \\
\hline & No & No & No & No & No & No \\
\hline & $\%$ & $\%$ & $\%$ & $\%$ & $\%$ & $\%$ \\
\hline \multirow[t]{2}{*}{$(\mathrm{T})$} & 9 & 5 & 18 & 2 & 3 & 7 \\
\hline & $28.1 \%$ & $15.6 \%$ & $56.2 \%$ & $16.6 \%$ & $25 \%$ & $58.3 \%$ \\
\hline \multirow[t]{2}{*}{ (CT) } & 2 & 8 & 22 & 0 & 2 & 10 \\
\hline & $6.25 \%$ & $25 \%$ & $68.5 \%$ & $0 \%$ & $16.6 \%$ & $83.3 \%$ \\
\hline \multirow[t]{2}{*}{ (E) } & 21 & 5 & 6 & 6 & 3 & \\
\hline & $65.6 \%$ & $15.6 \%$ & $18.7 \%$ & $50 \%$ & $25 \%$ & $25 \%$ \\
\hline \multirow[t]{2}{*}{$(\mathrm{CN})$} & 5 & 7 & 20 & 2 & 4 & 6 \\
\hline & $15.6 \%$ & $21.8 \%$ & $62.5 \%$ & $16.6 \%$ & $33.3 \%$ & $50 \%$ \\
\hline \multirow[t]{2}{*}{$(\mathrm{AMC})$} & 3 & 5 & 24 & 1 & 5 & 6 \\
\hline & $9.3 \%$ & $15.6 \%$ & $75 \%$ & $8.3 \%$ & $41.60 \%$ & $50 \%$ \\
\hline \multirow[t]{2}{*}{$(\mathrm{SXT})$} & 27 & 3 & 2 & 8 & 1 & \\
\hline & $84.3 \%$ & $9.3 \%$ & $6.2 \%$ & $66.6 \%$ & $8.3 \%$ & $25 \%$ \\
\hline \multirow[t]{2}{*}{ (CIP) } & 26 & 4 & 2 & 5 & 5 & 2 \\
\hline & $81.2 \%$ & $12.5 \%$ & $6.2 \%$ & $41.6 \%$ & $41.6 \%$ & $16.6 \%$ \\
\hline \multirow[t]{2}{*}{ (SAM) } & 0 & 7 & 25 & 1 & 1 & 10 \\
\hline & $0 \%$ & $21.8 \%$ & $78.1 \%$ & $8.3 \%$ & $8.3 \%$ & $83.3 \%$ \\
\hline \multirow[t]{2}{*}{ (CTX) } & 29 & 3 & 0 & 8 & 4 & 0 \\
\hline & $90.6 \%$ & $9.3 \%$ & $0 \%$ & $66.6 \%$ & $33.3 \%$ & $0 \%$ \\
\hline \multirow{2}{*}{ (DA) } & 5 & 7 & 20 & 2 & 4 & 6 \\
\hline & $15.6 \%$ & $21.8 \%$ & $62.5 \%$ & $16.6 \%$ & $33.3 \%$ & $50 \%$ \\
\hline \multirow[t]{2}{*}{ ENR) } & 27 & 5 & 0 & 8 & & 0 \\
\hline & $84.3 \%$ & $15.6 \%$ & $0 \%$ & $66.6 \%$ & $33.3 \%$ & $0 \%$ \\
\hline \multirow{2}{*}{$(\mathrm{OFX})$} & 26 & 5 & 1 & 6 & 6 & 0 \\
\hline & $81.2 \%$ & $15.6 \%$ & $3.1 \%$ & $50 \%$ & $50 \%$ & $0 \%$ \\
\hline \multirow{2}{*}{ (F300) } & 28 & & & & & \\
\hline & $87.5 \%$ & $12.5 \%$ & & & & \\
\hline
\end{tabular}

$\mathrm{S}=$ Sensitive, $\mathrm{M}=$ Moderate sensitive and $\mathrm{R}=$ Resistant 
Results showed that the prevalence $S$. aureus isolates was $19.1 \%$. $6.4 \%$ of the $S$. aureusisolates was coagulase positive strains. The lowest prevalence was Proteus spp. (7.4\%) L. monocytogens (4.3\%) and Klepsila (3.2\%).

\section{Bacterial Isolation from Examined Body Sites}

Results tabulated in Fig. 2 revealed the percentage of bacterial species from examined body organs (liver, lung and heart). The highest rate of isolation from organs was from the heart followed by liver and lung. Examination of all isolates of E. coli spp. and salmonella spp. collected from heart by API 20 test and PCR revealed that $32 / 35(91.4 \%)$ were E. coli spp. and 12/13 (92.3\%) were confirmed as Salmonella spp.

\section{Resistance Pattern of E. coli and Salmonella spp. Isolates}

As illustrated in Table 2, E. coli and Salmonella spp. isolated from heart blood showed high resistance to multiple drugs. Over $50 \%$ of both E. coli and Salmonella spp. isolates were found resistant against sulbactin-ampicillin, amoxicillin and claveulinic, colistin, oxytetracycline, clindamycin and gentamycin. However, nitrofuranation, enerofloxacine, trimethoprim and sulphamethaxole, ciprofloxacin, ofloxacine were highly (effective) sensitive against E. coli and Salmonella spp. isolates.

\section{Direct Parasitological Examination}

Chewing lice were detected in between feather of wings and body in 35/94 (37.2\%) of quails. Twenty seven (28.7\%) of quails harbored one or two species of nematode helminthes. The first one was Heterakis spp. which was recovered from the caeca whereas the second was Ascarida galli spp. which was recovered from the small intestine.

\section{Influenza A Virus Detection and Isolation Trials}

The trials for detection and isolation of influenza viruses in oral and cloaca swabs by direct detection by RT-PCR and allantoic fluids from inoculated SPF embryonated chicken eggs were found negative.

\section{Discussion}

Importance of wild birds as potential vectors of some zoonotic disease has received recent renewed empirical interest. Studying the existence of pathogens in wild birds may serve as a useful tool for examining the spread of other diseases amongst birds and from birds to others. However, information regarding the normal gastrointestinal bacterial flora is limited for the majority of wild bird species, with the few well-studied examples concentrating on bacteria that are zoonotic and/or related to avian species of commercial interest.

Migratory bird's play an important role in transmission of the diseases because of their great mobility from area to another which plays a role as potential vectors for disease may regard domestic animals and human health (Abulreesh et al., 2007). Quails pass through seashore of Sinai during autumn migration from Central Europe. They arrive at the shore exhausted and easily caught in hunters' nets because they fly very low as they reach shore. Many of the residents of that areas hunt these birds easily and either eat or sell it out in the public markets. In the present study, results revealed that despite none of tested quails showed characteristic clinical symptoms or pathological lesions, a high occurrence of some zoonotic bacterial species were detected among them indicating asymptomatic or carrier infections. These results are inconsistent with previous studies (Leveque et al., 2003; Benskin et al., 2009; Hamad et al., 2012). This finding could be explained for many reasons. First, the migratory quails can carry bacteria for several weeks without presenting any clinical signs. Second, it has been proven that the high ability of domestic quails to acquire infection more than in migratory quail (Medani et al., 2002). Finally, the migratory quails that capable of travelling long distance start its flight from Europe, the diseased one might not be able to share in journey or die without reaching the transient area in Egypt.

The Sampling techniques for detecting incidence of some pathogenic bacteria are a major factor affecting detection rate of the pathogens. Isolation rate was differing according to the sampling sites. Our results revealed that higher isolation rate of bacteria species was in cloaca swabs in compare with oral swabs. In addition, among the internal organs, isolation rate from heart was much higher than that from lung and liver. These results were supported by previous study of Roy et al. (2012).

E. coli spp. and Salmonella spp. are the most potential pathogens causing food poisoning and posing a zoonotic hazard. In this study, the presence of $E$. coli was the predominant pathogen reached $37.2 \%$ of the examined quails. A nearly similar finding was previously recorded by Awadallah et al. (2013) who described a prevalence of $(48 \%)$ in samples collected from wild birds in Egypt. A percentage of $(38 \%)$ were reported by Rogers (2006) in California, USA. However, lower E. coli infection rates of (1-18.7\%) was recorded in free living birds (Brittingham et al., 1988). The variation in prevalence rates may be attributed to the localities and bird feeding habits. Salmonella spp. Isolation rate reached $(21.6 \%)$ which was much higher than that was obtained by other studies (Vlahovic et al., 2004; Hedawy and El-Shorbagy, 2007). Compared with other studies, higher solation rate of Salmonella spp. in the current study may be attributed to the fact that wild birds may consume polluted food and water. This was previously supported by Fricker (1984) who stated that waste disposal sites increases the frequency of dispersion of enteric bacteria in migratory birds. 
In the current study, $S$. typhimurium was confirmed in 3 out of $13(23.07 \%)$ S. typhimurium is the most serotype commonly associated with wild birds (Benskin et al., 2009). Wild quails could be considered as true reservoirs in transmission of zoonotic E. coli and Salmonella due to their indirect contact with human habitations (Ahmed et al., 2011). Therefore, the potential role of migratory quails in transmission of infectious diseases should be considered.

In this study, the incidence $S$. aureus was $19.1 \%$. A similar result was agreed with a previous study (Hamad et al., 2012). Our results indicated that the migratory quails harbored some bacteria which might play a significant role in the epidemiology of some enteric bacterial pathogens. Similar results have been mentioned by Effat and Moursi (2005).

Detection of bacterial entero-pathogens in wild birds has applied through traditional microbiological techniques (Benskin et al., 2009). Our isolation was done through traditional microbiological techniques. $E$. coli and Salmonella spp. Isolates from heart blood were further examined by API 20 test and PCR. Results indicated that API and PCR identifications were more rapid and accurate diagnostic techniques matched with traditional techniques.

In poultry, antimicrobial agents are often continuously supplied as antimicrobial growth promoters and this has resulted in increased antibiotic selection pressure for resistant bacteria, resulting in their fecal flora containing a relatively high proportion of resistant bacteria. The use of antibiotics is supposed to be the most important factor promoting the emergence, selection and dissemination of antibiotic-resistant microorganisms in both veterinary and human medicine. Our results regarding the antimicrobial resistance pattern of E. coli and Salmonella isolates were in agreement with Roy et al. (2006) and Salehi and Reza (2010) who found that the antimicrobial resistance pattern was $50 \%$ or more of that isolates were multi-drug resistant against sulbactin-ampicillin, amoxicillin and claveulinic, colistin, oxtetracycline, clindamycin and gentamycin. However, it disagreed with that obtained by Hedawy and Wassel (2005). High sensitivity was showed in $80 \%$ of $E$. coli isolates was to nitrofuranation, enerofloxacine, trimethoprim,-sulphamethaxole, ciprofloxacin and ofloxacine. This finding was consistent with the findings of Blanco et al. (1997). In fact, contamination of foods with antibiotic resistant bacteria could be a major threat to public health Van et al. (2008). The diffusion of zoonotic bacteria resistant to antibiotics is an important concern for the treatment of human infections, because it can compromise the effectiveness of the therapy (Kilonzo-Nthenge et al., 2008). The increase in awareness about zoonotic infections could provide a better plan for the prevention and treatment.
Our results revealed a high incidence of one ectoparasite (chewing lice) which was detected in between feather of both wings. This finding was similar to that detected by Nursel (2010) who detect chewing lice spp. in wild quails during autumn migration. In addition, two nematode parasite species were identified. The first was identified as Heterakis spp. which was similar the finding recorded by Alan et al. (1979). In addition, Heterakis spp. was well documented in relation to blackhead in quail and/or other gallinaceous birds. The second was Ascardia gali which was recovered from the small intestine. This finding was agreed with the results of Williams et al. (2000) who found helminthes parasites in $28 \%$ of bobwhite quails.

Influenza viruses of several subtypes have been isolated from quails in North America, Europe, Asia and Africa through periodic surveillance and sporadic outbreaks. Quails could be intermediate host of IAVs Bahl et al. (2013). Wild quail may provide an optimal environment for the adaptation of wild bird AIV that could generate novel variants that can cross the species barrier to domestic poultry and human beings in spite of negative isolation trails against AIVs. Our data showed that AIVs were not detected in either oralorcloaca swabs of all quails. Similar results were clarified by Ferro et al. (2012) who mentioned that no virus was isolated from any of the suspicious samples tested. This finding might be attributed to short term of sample collection (autumn season). Therefore, the awareness to migratory birds as reservoir hosts for zoonotic pathogens should be raised.

\section{Conclusion}

Wild quail can be considered as potential vectors of zoonotic pathogens, including antimicrobial-resistant variants, which can be transferred to humans through direct contact or the food chain. Sensitivity of E. coli and Salmonella spp., strains to enrofloxacine, nitrofuranation which considered the drug of choice in case of infections. Migratory quails could serve to disperse bacteria between widely separated locations during migration. The opportunities exist for new health problems in wildlife populations emerge as well as new reservoirs of zoonotic disease to form. This work is basis of continuing efforts to periodical screening for pathogen from wild quail to predict future disease risks for wildlife and humans. Stimulating awareness to hunters, handlers and consumer about zoonotic pathogens is an important measure.

\section{Conflict of Interests}

The authors declare no conflict of interests with respect to the research, authorship and/or publication of 
this paper and has no direct financial relation with the commercial identities mentioned in this paper.

\section{Acknowledgment}

We thank Dr. Abdel SatarArafa for applying real time PCR and isolation trails for detection avian influenza virus.

\section{Author's Contributions}

The author and the co-author have equally contributed in the preparation development and publication of this manuscript.

\section{Ethics}

This article is original and contains unpublished materials. The corresponding author confirms that all of the other authors have read and approved the manuscript and no ethical issues involved.

\section{References}

Abulreesh, H. H., R. Goulder and G.W. Scott, 2007. Wild birds and human pathogens in the context ringing and migration. Ringing Migration, 23: 193-200.

DOI: $10.1080 / 03078698.2007 .9674363$

Acha, P.N. and B. Szyfres, 1987. Zoonosis and Communicable Diseases Man and Animals. 3rd Edn., Pan American Health Organization, Scientific and Technical Publications, Washington, DC. USA.

Ahmed, L.M., F.A. Al-Obaidi and S.M. Al-Shadeedi, 2011. Prevalence of some zoonotic bacteria in wild birds in Kirkuk city. AI-Anbar J. Vet. Sci., 4: 11-17.

Alan, K.A., H. Larry and J.H. Eve, 1979. Some parasitic and infectious diseases of bobwhite quail from Oklahoma. Oklahoma State University.

Alvarez, J., M. Sota, A.B. Vivanco, I. Perales and R. Cisterna et al., 2004. Development of a multiplex PCR technique for detection and epidemiological typing of salmonella in human clinical samples. J. Clin. Microbial, 42: 1734-1738.

DOI: 10.1128/JCM.42.4.1734-1738.2004

Aly, M.M., A. Arafa and M.K. Hassan, 2008. Epidemiological findings of outbreaks of disease caused by highly pathogenic H5N1 avian influenza virus in poultry in Egypt during 2006. Avian Dis., 52: 269-277. DOI: 10.1637/8166-103007-Reg.1

Awadallah, A.M., M.M. Abdallah and E.M. Rehab, 2013. Prevalence of zoonotic Escherichia coliandSalmonellaeinwild birds and humans in Egypt with emphasis on RAPD-PCR fingerprinting of E. coli. Global Veterinaria, 11: 781-788.
Bahl, J., S. Krauss, D. Kühnert, M. Fourment and G. Raven, 2013. Influenza A virus migration and persistence in North American wild birds. PLoSPathogen, 9: e1003570. DOI: 10.1371/journal.ppat.1003570

Benskin, C.M., K. Wilson, K. Jones and I.R. Hartley, 2009. Bacterial pathogens in wild birds: A review of the frequency and effects of infection. Biological Rev. Cambridge Philosophical Society, 84: 349-373.

Bertran, K., E. Perez-Ramirez, N. Busquets, R. Dolz and A. Ramis et al., 2011. Pathogenesis and transmissibility of highly (H7N1) and low (H7N9) pathogenic avian influenza virus infection in redlegged partridge (Alectoris rufa). Vet. Res., 42: 24. DOI: 10.1186/1297-9716-42-24

Blanco, J.E., M. Blanco, A. Mora and J. Blanco, 1997. Prevalence of bacterial resistance to quinolones and other antimicrobials among avian Escherichia coli strains isolated from septicemic and healthy chickens in Spain. Clin. Microbial, 35: 2184-2185. PMID: 9230413

Brittingham, M.C., S.A. Temple and R.M. Duncan, 1988. A survey of the prevalence of selected bacteria in wild birds. J. Wildl. Dis., 24: 299-307. DOI: 10.7589/0090-3558-24.2.299

Cole, D., D.J. Drum, D.E. Stalknecht, D.G. White and M.D. Lee et al., 2005. Free-living Canada Geese and antimicrobial resistance. Emerg, Infect. Dis., 11: 935-938. PMID: 15963291

Edwards, P.R. and W.H. Ewing, 1972. Identification of Enterobacter. 3rd Edn., Minneapolis, Burgess Publishing Co. USA.

Effat, A.E. and M.K. Moursi, 2005. Role of wild birds in transmission of protozoa and bacterial pathogens to domesticated birds in Ismailia province. J. Egypt. Vet. Med. Assoc., 65: 297-325

Ferro, P.J., O. Khan, C. Vuong, S.M. Reddy and L. LaCoste et al., 2012. Avian influenza virus investigation in wild bobwhite quail from Texas. Avian Dis., 56: 858-60. DOI: 10.1637/10197-041012-ResNote.1

Fricker, C.R., 1984. A note on salmonella excretion in the black headed gull (Larus ribibundus) feeding at sewage treatment works. J. Appl. Bacterial., 56: 499-502. PMID: 6746468

Hamad, M.A., A.M. Al-Aalim, S.Y.A. Al-Dabbagh and H.H. Ali, 2012. Detection of organ bacterial load in quails. Iraqi. J. Vet. Sci., 26: 47-51.

Hedawy, K.A.A. and F.A.A.Wassel, 2005. Studies on some bacterial agents causing mortalities in quail farms in Kena province. Assuit Vet. Med. J., 53: 251-257.

Hedawy, K.A.A. and M.M.A. El-Shorbagy, 2007. Role of some wild birds in transmitting some Bacterial agents among poultry farms in Sohag Governorate. Assuit Vet. Med. J., 53: 251-257. 
Kahn, L.H., 2006. Confronting zoonoses, linking human and veterinary medicine. Emerg. Infect. Dis., 12: 556-561. DOI: 10.3201/eid1204.050956

Kilonzo-Nthenge, A., S.N. Nahashon, F. Chen and N. Adefope, 2008. Prevalence and antimicrobial resistance of pathogenic bacteria in chicken and Guinea Fowl. Poultry Sci., 87: 1841-1848.

DOI: $10.3382 /$ ps.2007-00156

Kloos, W.E. and T.L. Bannerman, 1999. Staphylococcus and Micrococcus. In: Manual of Clinical Microbiology, Murray, P.R., E.J. Baron, M.A. Pfaller, F.C. Tenover and R.H. Yolken (Eds.), Washington, D.C. American Society for Microbiology, pp: 264-282.

Leveque, G., V. Forgetta, S. Morroll, A.M.L. Kenneth and M.S. Danielle et al., 2003. Allelic Variation in TLR4 Is Linked to Susceptibility to Salmonella enterica Serovar Typhimurium Infection in Chickens. Infect. Immun., 71: 1116-1124. DOI: 10.1128/IAI.71.3.1116-1124.2003

Liasi, S.A., T.I. Azmi, M.D. Hassan, M. Shuhaimi and M. Rosfariza et al., 2009. Antimicrobial activity and antibiotic sensitivity of three isolates of lactic acid bacteria from fermented fish product. Budu. Malaysian J. Microbial., 5: 33-37.

McDaniels, A.E., E.W. Rice, A. Reyes, C.H. Johnson and R.A. Haugland et al., 1996. Conformational Identification of Escherichia coli, a Comparison of Genotypic and Phenotypic Assays for Glutamate Decarboxylase and b-DGlucuronidase. Applied Environ. Microbiol., 62: 3350-3354.

Medani, G.G., M.A. Mohamoud, M.M. Hussein and M.M. Sabry, 2002. Comparative study upon bacterial infection with special reference to Enterobacteriaceae in Japanese and migratory quails. J. Egypt Vet. Med. Assoc., 62: 42-48.

Middleton, J.H. and A. Ambrose, 2005. Enumeration and antibiotic resistance patterns of fecal indicator organisms isolated from migratory Canada geese (Branta canadensis). J. Wildl. Dis., 41: 334-341. PMID: 16107668

Mohamed, K.M., M.E. Hala and S. Soheir, 2001. Bacteriological and pathological studies on dead-in shell in quail farms in Ismailia. Suez Canal Vet. Med. J., 1: 437-457.

Monday, S.R. and G.A. Bohach, 1999. Use of multiplex PCR to detect classical and newly described pyrogenic toxin genes in staphylococcal isolates. J. Clin. Microbiol, 37: 3411-3414. PMID: 10488222

NCCLS, 2009. Methods for dilution antimicrobial susceptibility tests for bacteria that grow aerobically-fourth edition; approved standard (NCCLS document M7-A4). Villanova, Pa: National Committee for Clinical Laboratory Standards.
Nursel, A., 2010. The presence of chewing lice (Insecta: Phthiraptera) species on wild quails (Coturnix coturnix). J. Anim. Vet. Adv., 9: 1377-1379. DOI: $10.3923 /$ javaa.2010.1377.1379

Rogers, K.H., 2006. Prevalence of pathogenic enteric bacteria in wild birds associated with agriculture in Humboldt County, California. MSc of Thesis, Humboldt State University, California, USA.

Roy, P., V. Purushothaman, A. Koteeswaran and A.S. Dhillon, 2006. Isolation, characterization and antimicrobial drug resistance pattern of Escherichia coli Isolated from Japanese quail and their environment. J. Appl. Poult. Res., 15: 442-446. DOI: $10.1093 /$ japr/15.3.442

Roy, S.R., M.B. Rahman, J. Hassan and K.N.H. Nazir, 2012. Isolation and identification of bacterial flora from internal organs of broiler and their antibiogram studies. Microbes Health, 1: 72-75.

DOI: $10.3329 / \mathrm{mh} . v 1 \mathrm{i} 2.14094$

Salehi, M. and G. Reza, 2010. Phenotypic and genotypic properties of Escherichia coli isolated from colisepticemic cases of Japanese quail. Trop. Ainm. Health Prod., 42: 1497-1504. DOI: 10.1007/s11250010-9583-5

Smith, N., 1999. To field-dress a Deer, Pennsylvania game news, pennsylvania game commission, Harrisburg, PA.USDA-Food Safety Inspection Service, Department of Agriculture, USA.

Stohr, K. and F.X. Melsin, 1997. The role of veterinary public health in the prevention of zoonosis. Arch. Virol. J., 13: 207-218.

Thontiravong, A., P. Kitikoon, S. Wannaratana, R. Tantilertcharoen and R. Tuanudom et al., 2012. Quail as a potential mixing vessel for the generation of new reasserting influenza A viruses. Vet. Microbiol., 160: 305-313.

DOI: $10.1016 /$ j.vetmic. 2012.05 .043

Van, T.T.H., J. Chin, T. Chapmanb, L.T. Tranc and P.J. Coloe, 2008. Safety of raw meat and shellfish in Vietnam: An analysis of Escherichia coli isolations for antibiotic resistance and virulence genes. Int. J. Food Microbiol., 124: 217-223.

DOI: 10.1016/j.ijfoodmicro.2008.03.029

Vlahovic, K., B. Matica, I. Bata, M. Pavlak and Z. Pavicic et al., 2004. Campylobacter, Salmonella and Chlamydia in free-living birds of Croatia. Eur. J. Wildl. Res., 50: 127-132. DOI: 10.1007/s10344004-0052-1

Williams, C.K., W.R. Davidson, R.S. Lutz and R.D. Applegate, 2000. Health Status of Northern Bobwhite Quail (Colinus virginianus) in Eastern Kansas. Avian Dis., 44: 953-956.

DOI: $10.2307 / 1593071$ 